\title{
THE POTENTIATION OF EXOGENOUS INSULIN BY TOLBUTAMIDE IN DEPANCREATIZED DOGS ${ }^{2}$
}

\author{
BY RAYMOND CAREN AND LUCILLE CORBO \\ (From The Institute for Medical Research, Cedars of Lebanon Hospital, and the Department of \\ Medicine, School of Medicine, University of Califormia at Los Angeles, \\ Las Angeles, Cal.)
}

(Submitted for publication April 8, 1957; accepted July 11, 1957)

The mode of action of the hypoglycemic sulfonylureas has remained obscure despite the great interest and extensive clinical trial of these agents in the treatment of diabetes mellitus. A thorough understanding of the mechanism of action is essential in view of their potentially extensive use in diabetes.

Several modes of action have been suggested: a) inhibition of the pancreatic alpha cells resulting in a decreased production of glucagon $(1) ; b$ ) increased insulin production due to stimulation of the pancreatic beta cells $(2)$; c) inhibition of insulinase resulting in decreased inactivation of insulin (3) ; and d) inhibition of one or more enzymes of the liver resulting in decreased hepatic glucose output (4-6).

It is generally agreed by most investigators that the sulfonylureas do not affect the alpha cells and so do not inhibit glucagon secretion $(6,7)$. Additional evidence negating this theory is the absence of hypoglycemic action in completely alloxanized animals $(8,9)$.

Vaughan (5) has reported that the hypoglycemia may be due to inhibition of one or more of

1 This work was carried out under Research Grant No. A-505 from the National Institute of Arthritis and Metabolic Diseases of the National Institutes of Health, Public Health Service, and was supported in part by a grant from The Upjohn Co., Kalamazoo, Michigan. the liver enzymes resulting in diminished glucose output. If this were so, one would expect hypoglycemic action in depancreatized and alloxanized animals. This does not occur.

The beta cell stimulation (2) and insulin potentiation theories $(3,10,11)$ are the two most generally considered mechanisms of action. We have sought to clarify this problem by determining whether or not tolbutamide (Orinase $\left.{ }^{2}\right)^{2}$ could enhance the action of insulin in the absence of all pancreatic tissue. If this occurred, it would mean the mode of action (or at least one of the mechanisms) was to potentiate insulin activity since the animals had no beta cells and so lacked a source of endogenous insulin. This work is a report of the effect of tolbutamide on the insulin tolerance tests of depancreatized dogs.

\section{METHODS}

Mongrel male and female dogs were pancreatectomized with utmost care to assure complete removal of all pancreatic tissue. They were maintained on milk, canned dog food, and regular dog meal, and were allowed a oneweek recovery period during which 8 units of NPH insulin were given daily. From then on the animals received 5 units of regular insulin once per day. This was given 18 hours prior to the experiment of the following day.

After the seven-day recovery period, insulin tolerance

2 Trade name for tolbutamide, The Upjohn Co.

TABLE I

The effect of tolbutamide on the insulin tolerance tests of depancreatized dogs using 0.25 unit per Kg. of insulin

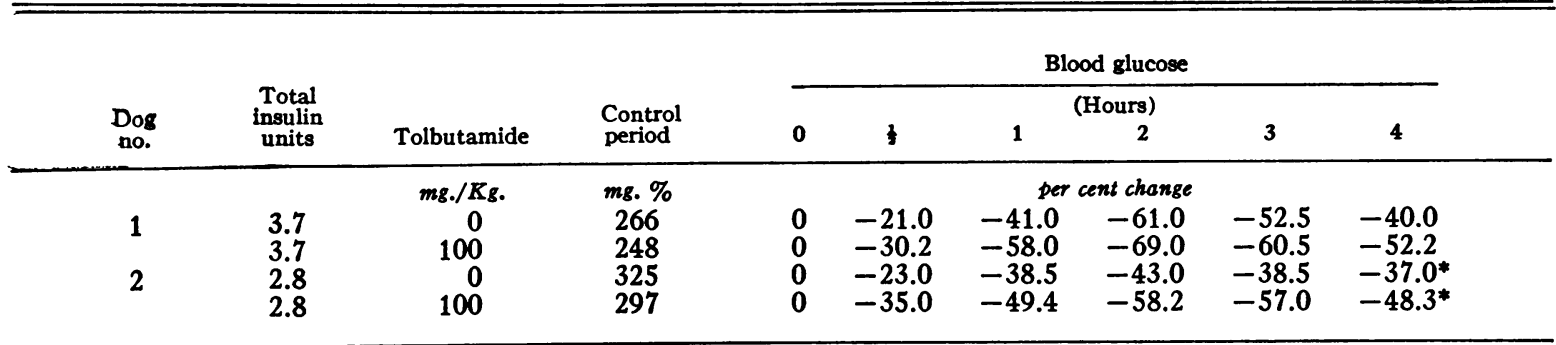

* Three and one-half hours. 
TABLE II

The effect of tolbutamide on the insulin tolerance tests of depancreatized dogs using 0.20 unit per $K g$. of insulin

\begin{tabular}{|c|c|c|c|c|c|c|c|c|c|}
\hline \multirow[b]{2}{*}{$\begin{array}{l}\text { Dog } \\
\text { no. }\end{array}$} & \multirow[b]{2}{*}{ 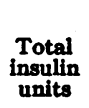 } & \multirow[b]{2}{*}{ Tolbutamide } & \multirow[b]{2}{*}{$\begin{array}{l}\text { Control } \\
\text { period }\end{array}$} & \multicolumn{6}{|c|}{ Blood glucose } \\
\hline & & & & $\mathbf{0}$ & $\mathbf{3}$ & 1 & $\begin{array}{l}\text { Hours) } \\
2\end{array}$ & 3* & $4 \dagger$ \\
\hline & & ms./Kg. & mg. \% & \multicolumn{6}{|c|}{ per cent change } \\
\hline 2 & $\begin{array}{l}2.2 \\
2.2 \\
2.2\end{array}$ & $\begin{array}{r}0 \\
0 \\
100\end{array}$ & $\begin{array}{l}358 \\
334 \\
326 \\
368\end{array}$ & $\begin{array}{l}\mathbf{0} \\
\mathbf{0} \\
\mathbf{0} \\
0\end{array}$ & $\begin{array}{l}-30.2 \\
-14.4 \\
-30.0 \\
-10.1\end{array}$ & $\begin{array}{l}-43.8 \\
-31.8 \\
-47.4\end{array}$ & $\begin{array}{l}-52.0 \\
-44.5 \\
-57.5\end{array}$ & $\begin{array}{l}-38.8 \\
-28.8 \\
-65.7\end{array}$ & $\begin{array}{l}-18.7 \\
-11.7 \\
-67.2 \\
-0.0\end{array}$ \\
\hline 7 & $\begin{array}{l}2.1 \\
2.1 \\
1.8 \\
1.8 \\
1.8\end{array}$ & $\begin{array}{r}0 \\
100 \\
0 \\
0 \\
100\end{array}$ & $\begin{array}{l}354 \\
386 \\
365 \\
334 \\
400\end{array}$ & $\begin{array}{l}0 \\
0 \\
0 \\
0 \\
0\end{array}$ & $\begin{array}{l}-14.4 \\
-25.4 \\
-18.9 \\
-11.4 \\
-15.5\end{array}$ & $\begin{array}{l}-30.3 \\
-44.6 \\
-23.9 \\
-20.4 \\
-32.0\end{array}$ & $\begin{array}{l}-31.5 \\
-65.0 \\
-32.1 \\
-27.7 \\
-46.3\end{array}$ & $\begin{array}{l}-26.6 \\
-54.5 \\
-23.9 \\
-20.4 \\
-38.8\end{array}$ & $\begin{array}{r}-6.5 \\
-44.6 \\
-20.0 \\
0.0 \\
-35.8\end{array}$ \\
\hline
\end{tabular}

$*$ Mean $\pm S E\{$ control, $27.7 \pm 3.1$ $\left\{\begin{array}{l}\text { test, } 53.0 \pm 7.8(0.02>p>0.01) \\ \text { t }\end{array}\right.$

tests were performed with varying doses of regular insulin $(0.01,0.025,0.20,0.25$ units per $\mathrm{Kg}$.). Following an overnight fast, a blood specimen was obtained from a limb vein, and the calculated quantity of insulin was administered intravenously in a single injection requiring five to ten seconds. Specimens of venous blood were obtained at zero, one-half, one, two, three and sometimes four hours. Following completion of the test the animals were given their maintenance dose of 5 units of regular insulin and were fed.

On the following day the test was repeated on the same animal using the same dose of insulin. However, one hour prior to the administration of insulin, the animal was given the sodium salt of tolbutamide (100 mg. per $\mathrm{Kg}$.) intravenously dissolved in $4 \mathrm{ml}$. normal saline. Blood samples were then obtained at zero, one-half, one, two, three and sometimes four hours. In several cases control insulin tolerance tests were repeated on two successive days before performing the tolbutamide-insulin test. This was done to make certain of the constancy of $\dagger$ Mean $\pm S E\left\{\begin{array}{l}\text { control, } 10.9 \pm 3.1 . \\ \text { test, } 48.1 \pm 9.4(0.01>p>0.001)\end{array}\right.$

the control curves, thus ruling out any artifact which might arise from performing the control test first. After once having received tolbutamide, the dog was not used again for at least five days to make certain all the sulfonylurea had been excreted.

In order to make certain of the completeness of the pancreatectomy in each dog, tolbutamide was injected intravenously (100 mg. per $\mathrm{Kg}$.) 18 hours after the last dose of regular insulin. Blood glucose was determined at zero, one-half, one, two and three hours in two animals and at zero and one hour in all the others. All animals were fasted overnight. As an additional check on the completeness of the pancreatectomy, one-third of the animals were sacrificed and examined post mortem. No pancreatic tissue was found in any animal examined.

The animals were not anesthetized and were secured with a leash to prevent them from moving about during the experiment.

Blood glucose was determined by the Nelson modification of the Somogyi method (12).

TABLE III

The effect of tolbutomide on the insulin tolerance tests of depancreatized dogs using 0.025 unit per $K_{g}$. of insulin

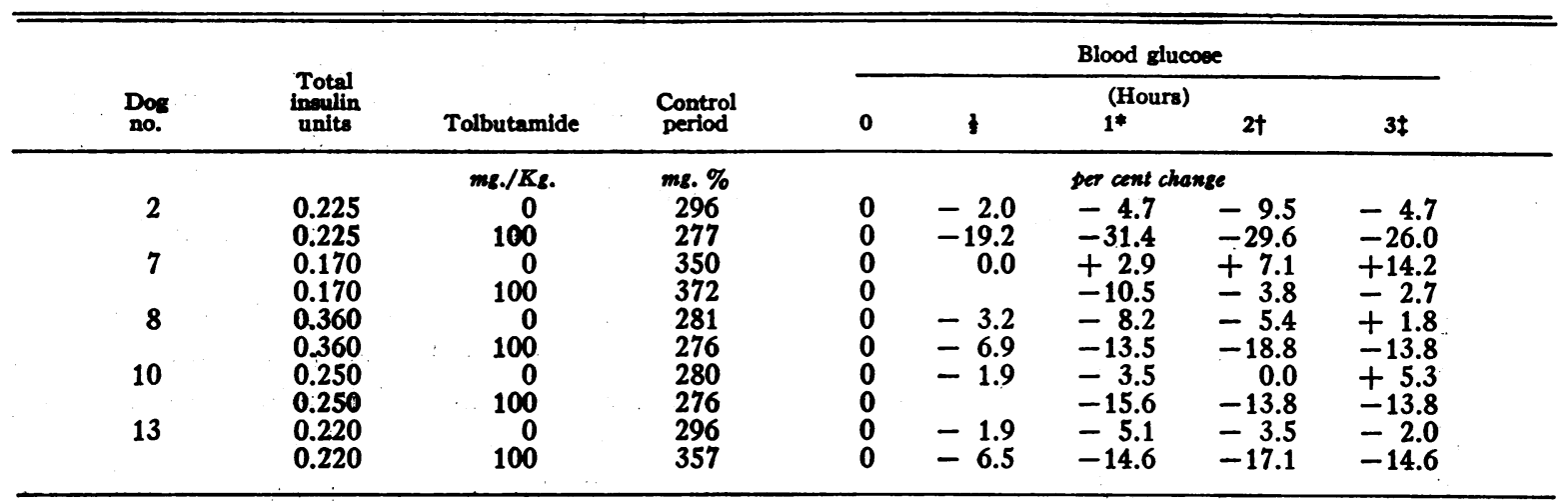

$*$ Mean $\pm \operatorname{SE}\left\{\begin{array}{l}\text { control, }-3.7 \pm 1.8 . \\ \text { test, }-17.1 \pm 3.7(0.02>p>0.01)\end{array}\right.$

$\ddagger$ Mean $\pm \mathrm{SE}\{$ control, $+2.91 \pm 3.1$.

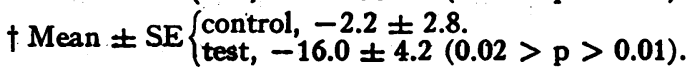


TABLE IV

The effect of tolbutamide on the insulin tolerance tests of depancreatised dogs using 0.01 unit per $\mathrm{Kg}$. of insulin

\begin{tabular}{|c|c|c|c|c|c|c|c|c|}
\hline \multirow[b]{2}{*}{$\begin{array}{l}\text { Dog } \\
\text { no. }\end{array}$} & \multirow[b]{2}{*}{$\underset{\substack{\text { Total } \\
\text { insulin } \\
\text { units }}}{\text {. }}$} & \multirow[b]{2}{*}{ Tolbutamide } & \multirow[b]{2}{*}{$\begin{array}{l}\text { Control } \\
\text { period }\end{array}$} & \multicolumn{5}{|c|}{ Blood glucose } \\
\hline & & & & $\mathbf{0}$ & b & $\begin{array}{l}\text { (Hours) } \\
1\end{array}$ & 2 & 3 \\
\hline & & ms./Kg. & ms. \% & \multicolumn{5}{|c|}{ per cent change } \\
\hline $\begin{array}{l}10 \\
11\end{array}$ & $\begin{array}{l}0.10 \\
0.10 \\
0.09 \\
0.09\end{array}$ & $\begin{array}{r}0 \\
100 \\
0 \\
100\end{array}$ & $\begin{array}{l}214 \\
277 \\
246 \\
277\end{array}$ & $\begin{array}{l}\mathbf{0} \\
\mathbf{0} \\
\mathbf{0} \\
\mathbf{0}\end{array}$ & $\begin{array}{l}+5.8 \\
-6.9 \\
-2.0 \\
-6.9\end{array}$ & $\begin{array}{l}+3.7 \\
-3.6 \\
+9.0 \\
-5.4\end{array}$ & $\begin{array}{c}+5.8 \\
-3.6 \\
0 \\
0\end{array}$ & $\begin{array}{r}+9.2 \\
+5.4 \\
+11.4 \\
0\end{array}$ \\
\hline
\end{tabular}

\section{RESULTS}

The data are expressed as per cent change from the control blood glucose value rather then in absolute figures. This permitted comparison from animal to animal regardless of the difference in the control values.

The effect of tolbutamide on the insulin tolerance tests of depancreatized dogs using 0.25 unit per $\mathrm{Kg}$. of insulin is shown in Table I. During the four hours of observation no significant effect was seen.

When the insulin dosage was reduced to 0.20 unit per $\mathrm{Kg}$., (Table II), a potentiating effect by tolbutamide became evident during the third and fourth hours. When submitted to statistical analysis the difference was found to be significant.

When 0.025 unit per $\mathrm{Kg}$. of insulin was used (Table III), augmented insulin action was apparent in one-half hour, well established by the end of the first hour, and continued during the

TABLE V

The effect of intravenous tolbutamide (100 mg. per $K g$. ) on blood glucose of totally depancreatized dogs in the absence of exogenous insulin

\begin{tabular}{|c|c|c|c|c|}
\hline \multirow[b]{2}{*}{$\begin{array}{l}\text { Dos } \\
\text { no. }\end{array}$} & \multicolumn{4}{|c|}{ Blood glucose } \\
\hline & $\mathbf{0}$ & 1 & 2 & 3 \\
\hline $\begin{array}{r}2 \\
2 \\
4 \\
7 \\
8 \\
8 \\
8 \\
10 \\
10 \\
11 \\
11 \\
13 \\
13\end{array}$ & $\begin{array}{l}277 \\
326 \\
350 \\
380 \\
272 \\
278 \\
264 \\
258 \\
260 \\
258 \\
280 \\
282 \\
358\end{array}$ & $\begin{array}{l}\text { ms. } \\
277 \\
326 \\
386 \\
400 \\
276 \\
282 \\
284 \\
277 \\
260 \\
277 \\
310 \\
314 \\
367\end{array}$ & 310 & 310 \\
\hline
\end{tabular}

three hours of observation. Thus, the smaller the quantity of insulin used, the earlier the potentiating effect of tolbutamide become evident.

Two dogs were given 0.01 unit per $\mathrm{Kg}$. of insulin (Table IV). The dosage was so small that no hypoglycemic effect occurred in the control tests. However, when tolbutamide was administered, the same amount of insulin caused a maximal fall of blood glucose in one-half hour and a mild depression which persisted for three hours in Dog 10 and for two hours in Dog 11.

The effect of intravenous tolbutamide on the blood glucose of depancreatized dogs in the absence of any insulin is shown in Table V. Tolbutamide alone did not depress the blood glucose of any animal used in this work.

\section{DISCUSSION}

The data show that tolbutamide potentiated the action of exogenous insulin in the absence of all pancreatic tissue. Since the depancreatized animal no longer possessed beta cells and so lacked a source of endogenous insulin, one must conclude that the enhanced hypoglycemic effect of the insulin was due to potentiation by tolbutamide.

The inability of intravenous tolbutamide to lower the blood glucose in each animal when insulin was not administered showed that there was not enough endogenous insulin present to lower the blood glucose.

The apparent absence of insulin potentiation by tolbutamide during the first two hours when relatively large amounts of insulin were used may have been due to the fact that there was such an excess of insulin that its hypoglycemic action concealed or overshadowed the augmenting effect of the sulfonylurea. However, as more time elapsed and the concentration of the insulin diminished, the 
augmenting effect of tolbutamide became evident. Consequently, the smaller the insulin dosage, the earlier the sulfonylurea effect occurred; and, the larger the insulin dosage, the longer the time required to demonstrate the potentiation.

Fritz, Morton, Weinstein, and Levine (13) were unable to demonstrate potentiation of exogenous insulin activity by carbutamide in depancreatized dogs maintained on constant intravenous infusions of insulin. These were almost the same experiments that we performed but with one significant difference. Insulin was administered in a continuous infusion during a three- to four-hour period, whereas we gave the insulin in a single injection requiring only a few seconds. By providing a constant and continuous source of insulin an excess was always maintained so that the concentration never fell as in our experiments. Thus the potentiating effect of the carbutamide was overshadowed and never observed during the course of the experiment by these investigators. Another way of expressing the above is that their animals were always maintained under the conditions of the first two hours of our higher insulin dosage experiments. This factor may account for the conflicting results of different investigators regarding potentiation of exogenous insulin by the sulfonylureas.

This work showed that one of the mechanisms of tolbutamide action was to enhance both the intensity and duration of insulin action. Prolonging the duration of action appears to be the more important of the two. The maximal augmentation of intensity did not appear to be very large. However, by prolonging the duration of action, this agent probably achieves most of its clinical effect.

Although insulinase inhibition is one way of accounting for insulin potentiation by the sulfonylureas, it is not necessarily the only explanation. Augmented insulin action could occur by some other unexplained mechanism. For example, it is conceivable that endogenous and extracted insulin could differ in some unknown manner and because of this difference the sulfonylureas potentiate the former, and have a much smaller effect on extracted insulin. This explanation would best fit all the known facts of sulfonylurea hypoglycemic action. Very little is known about insulin differences; therefore, the above is merely speculation. It does, however, serve to show that insulin potentiation might be explained without invoking the inhibition of insulinase.

The facts which have been marshalled in favor of the beta cell stimulation theory also support the insulin potentiation theory. Failure to lower blood glucose in the depancreatized animal can be explained by the absence of insulin as well as by the absence of beta cells. Since insulin is not available in the depancreatized or completely alloxanized animal, no potentiation of insulin activity can be expected. The supposed inability of the sulfonylureas to reduce the insulin requirement of totally depancreatized people (14) and juvenile diabetics (15) is given as evidence against the insulin potentiation concept. However, various investigators have reported a lowering of the insulin requirement of juvenile diabetics (16) and depancreatized dogs (17).

These substances probably have more than one mechanism of action. Most experimental facts to date favor the combination of insulin potentiation (endogenous and/or exogenous) and beta cell stimulation. Thus, tolbutamide probably exerts a true insulin effect, although indirectly, despite conflicting reports regarding peripheral insulinlike action.

\section{SUMMARY}

1. Tolbutamide (Orinase ${ }^{(8)}$ ) was found to potentiate the action of exogenous insulin in the absence of all pancreatic tissue.

2. One mechanism of tolbutamide action was to augment both the intensity and duration of insulin activity. Prolonging the duration appears to be the more important of the two.

\section{REFERENCES}

1. Holt, C. V., Holt, L. V., Kröner, B., and Kühnau, J., Chemische Ausschaltung der A-Zellen der Langerhansschen Inseln. Arch. f. exper. Path. u. Pharmakol., 1955, 224, 66.

2. Loubatières, A., L'utilisation de certaines substances sulfamidées dans le traitment du diabète sucré expérimental; recherches personelles (1942-1946). Presse méd., 1955, 63, 1701.

3. Mirsky, I. A., Perisutti, G., and Diengott, D., The inhibition of insulinase by hypoglycemic sulfonamides. Metabolism, 1956, 5, 156.

4. Tyberghein, J. M., Halsey, Y. D., and Williams, R. H., Action of butyltolylsulfonylurea on liver gly- 
cogenolysis. Proc. Soc. Exper. Biol. \& Med, 1956, $92,322$.

5. Vaughan, M., In vitro -studies on the action of sulfonamide hypoglycemic agents. Science, 1956, 123, 885.

6. Ferner, H., and Runge, W., Die Langerhansschen Inseln von Diabetikern nach Behandlung mitdem oralen Antidiabetikum BZ-55. Deutsche med. Wchnschr., 1956, 81, 331.

7. Creutzfeldt, W., and Tecklenborg, E., Synthalinhypoglykämie, A-Zellen und Glucagon. Klin. Wchnschr., 1955, 33, 43.

8. Chen, K. K., Anderson, R. C., and Maze, N., Hypoglycemic action of sulfanilamidocyclopropylthiazole in rabbits, and its reversal by alloxan. Proc. Soc. Exper. Biol. \& Med., 1946, 63, 483.

9. Mirsky, I. A., Perisutti, G., and Jinks, R., Ineffectiveness of sulfonylureas in alloxan diabetic rats. Proc. Soc. Exper. Biol. \& Med., 1956, 91, 475.

10. Campbell, J., The action of BZ-55 in dogs. Part II. Observations on depancreatized and metahypophyseal diabetic dogs. Canad. M. A. J., 1956, 74, 962.
11. Sirek, A., and Sirek, O. V., The action of BZ-55 in dogs. Part I. Observations on depancreatized and Houssay dogs. Canad. M. A. J., 1956, 74, 960.

12. Nelson, N, A photometric adaptation of the Somogyi method for the determination of glucose. J. Biol. Chem., 1944, 153, 375.

13. Fritz, I. B., Morton, J. V., Weinstein, M., and Levine, $R$., Studies on the mechanism of action of the sulfonylureas. Metabolism, 1956, 5, 744.

14. Goetz, F. C., Gilbertsen, A. S., and Josephson, V., Acute effects of Orinase on peripheral glucose utilization. Metabolism, 1956, 5, 788.

15. Dolger, H., Clinical experience with Orinase. Metabolism, 1956, 5, 947.

16. Duncan, G. G., Joiner, C. L., and Lee, C. T., Methods of selection of diabetic patients sensitive to sulfonylurea compounds. Metabolism, 1956, 5, 964.

17. Kirtley, W. R., Ridolfo, A. S., Root, M. A., and Anderson, R. C., Clinical and pharmacological effects of substance BZ-55 in diabetes. Diabetes, 1956, 5, 351. 